\title{
Living with shifting borders: peripheralisation and the production of invisibility
}

\author{
Cathrine Brun, \\ Centre for Development and Emergency Practice \\ School of Architecture \\ Oxford Brookes University
}

Email: cbrun@brookes.ac.uk

\section{Accepted for publication in Geopolitics}

\section{Keywords:}

Shifting borders, everyday spaces, in/visibility, Sri Lanka, Georgia, feminist geopolitics

\section{Acknowledgements}

Many thanks to colleagues and friends in Georgia and Sri Lanka who have continued to include me in their work over the years. Thanks: to Julia Kharashvili and Lika Margania of "Consent" who introduced me to the Georgian Village; to the editors of the special issue for inviting me into this project; to Kathrin Hörschelmann and Matt Benwell for your productive comments; to three anonymous reviewers for the most generous and positive feedback and to Nicholas Van Hear for the space to write.

\begin{abstract}
The article analyses the experiences and material impacts of shifting borders in the historical case of Sri Lanka's civil war and the contemporary case of shifting border between Georgia and South Ossetia. The two cases point to some lesser known geopolitical practices in which border-shifts and strengthening of control in contested areas take place without much international attention, partly because the shifts are so minor and gradual that they do not reach the news headlines. Living with shifting borders create a state of inbetweenness and losing of control, where forms of visibility and invisibility produces individual uncertainties and vulnerabilities in homeplaces and people's everyday lives. By analysing the borderland and bordershifts from the perspective of the peripheral, the article emphasises the ways in which border practices become part of social action through a rescaling of the understanding of the border encouraged by feminist geopolitics. The article begins by discussing what borders may mean and how borders shift and may produce particular forms of visibility and invisibility. Then the contexts of the Sri Lankan and Georgian villages are introduced before a short discussion of the methods applied. The article then analyses how the bordershifts create particular material and symbolic outcomes, an experience of 'displacement in place, and the particular invisibilities created on the ground in the two cases. The article concludes by reflecting on how border-practices produce forms of visibility and invisibility that continue to render people in the borderlands peripheral.
\end{abstract}


In the Borderlands

you are the battleground

where enemies are kin to each other;

you are at home, a stranger,

the border disputes have been settled

the volley of shots have shattered the truce

you are wounded, lost in action

dead, fighting back;

(...)

To survive the Borderlands

you must live sin fronteras ${ }^{1}$

be a crossroads. ${ }^{2}$

\section{Introduction}

Borders and borderlands are imprinted by contested powers, they are not stable entities, they change character, they may be strengthened, demarcated in new ways, and they may shift. When a border shifts, physically, materially, socially or symbolically, it creates insecurity and radical uncertainty for some, particularly for those in the borderland. The borderland, or the frontier, is an ambivalent - and often violent - place as the poem above by Gloria Anzaldúa ${ }^{3}$ illustrates. The frontier may be both peripheral and central at the same time; it may form the margin of a territory, but is often strategically and militarily very important. The border represents a central demarcation of the borderland. With shifting borders, the frontier becomes an unstable, unpredictable and unsettled place.

While borderlands may be strategically important, Goodhand ${ }^{4}$ shows that borderlands are often neglected by policymakers where a state-centred view of the world is more prominent. People dwelling in the borderland are often considered peripheral to the state and neglected, rendered invisible and silenced. Frontiers may enable a particular control of people and a certain sense of exception ${ }^{5}$ This article addresses the ways in which border-shifts enable processes of peripheralisation that intersects with security politics to create particular forms of visibility and invisiblity of the borderland-subjects inhabiting the frontiers. I explore this experience of peripheralisation by engaging with two situations of shifting borders: the historical case of eastern Sri Lanka during the civil war that ended in 2009 and the current unstable border between Georgia and South Ossetia. My intention - and the reason for exploring these cases together - is to point to some lesser known geopolitical practices in which border-shifts and strengthening of control in contested areas take place without much international attention, partly because the shifts are so minor and gradual that they do not reach the news headlines. By engaging with dynamics and tensions between visibility and invisibility, I aim to 
switch the lens in border areas from the macro geopolitical processes of the moving borders to the representational consequences of those shifts on the ground and in people's everyday lives.

Analysing the borderland from the perspective of the peripheral and how it is experienced in everyday lives enable a rescaling of the understanding of the border encouraged by feminist geopolitics. ${ }^{6}$ I am inspired by Marieke Borren's ${ }^{7}$ interpretation of Hannah Arendt's ${ }^{8}$ discussion of power, politics and the space of appearance which opens up for a particular exploration of the ways in which people in the borderlands are rendered invisible and vulnerable. I begin the article by discussing what borders may mean and how borders shift and may produce particular forms of visibility and invisibility. I then briefly introduce the context and the methodology before I show how border-shifts create particular symbolic and material outcomes, 'displacement in place' and particular invisibilities.

\section{The power of vision: production of visibility and invisibility in the borderland}

The material practices on 'the border', such as erecting walls and barriers, building checkpoints and securitizing the borderlands, have become main tools for controlling population movement, securing resources and for producing and enabling symbolic power internationally and nationally. Currently, the way borders are theorised may be traced back to the events marking the end of the cold war which brought 'territory' and 'borders' back into the popular and academic imagination. Old states vanished and new ones appeared in the process commonly known as 'Balkanisation' ${ }^{9}$, initially used to describe fragmentation after disintegration of the Ottoman and Austro-Hungarian empire. Much attention has been given to those wars that created new borders and to regions were borders have changed meaning ${ }^{10}$ such as the borders between Georgia, South Ossetia and Russia. Less attention is perhaps directed towards the violence that reinstates the "national order of things", a one-nation narrative, enabled through a "victor's peace" such as in the case of Sri Lanka's nearly thirty year long civil war.11 Common for conflicts where new borders are established or where the one-nation narrative is re-instated and physical borders removed, is that border practices become part of social action. Theorising borders therefore becomes a way of theorising and analysing the social. ${ }^{12}$ In this context, it is useful to engage with feminist geopolitics which challenges the dominant scale of traditional geopolitical inquiry by drawing attention to the everyday and the embodied sites and discourses through which transnational economic and political relations are forged and contested. ${ }^{13}$ Casolo and Doshi $^{14}$, for example, show how geopolitics are produced and reworked through placebased meanings and struggles. When borders shift, violence takes place through the interconnections between different scales. ${ }^{15}$ In re-scaling geopolitical inquiry, feminist scholars have attended to the uneven ways in which geopolitical processes shape the lives of differently situated populations. ${ }^{16}$ Even the most intimate and everyday aspects of life are key sites where geopolitical power is (re)produced and negotiated. ${ }^{17}$ With 
feminist geopolitics, I consider the shifting borders analysed here as the meeting points between embodied experiences and geopolitical tactics.

Border-shifts are expressions of how economy, culture and politics come together as forces working upon each other. Sometimes, border practices expand and move further away from the line that represents the border through buffer zones, displacement, and institutional arrangements. Studies have shown how borders become diffused throughout society and extended off-shore, inland, abroad and into cyberspace. ${ }^{18}$ But equally important for the analysis here, is the movement of physical borders. I show how borders are in a state of flux and shift in many ways: they may change location, the border practices may dislocate, expand and disappear at one scale, but continue to live on at other scales. The cases in Sri Lanka and Georgia explored in this article represent contested borders and are analysed as border-practices that aspire to form or reestablish state borders. The meaning of the 'border' in the two cases discussed fluctuates between borders that act like nation state borders and borders that signify boundaries or divisions - between groups of people.

Importantly, borderlands - or the frontiers - enable and represent the contested nature of the border. ${ }^{19}$ The borders and borderlands remain spaces of securitisation where anticipation of violence governs border practices. ${ }^{20}$ Borders created by force during war or upheavals become reality through the practices of those who manage the borders and by those who have to cross and relate to the borders to perform their everyday lives. When the border is not given, not static, and associated with violence, everyday life is also in flux and displacement takes place in particular ways when borders shift violently. While staying put, the existence is split between here and there: the context is difficult to grasp because institutions and regulatory regimes change. Living with shifting borders may thus result in a feeling of inbetweenness and losing of control. A lost access to context ${ }^{21}$ emerges through a situation similar to, but not the same as, statelessness. In Hannah Arendt's ${ }^{22}$ understanding, it is the pathologies of political action and citizenship that distinguishes statelessness: a situation of public invisibility and natural visibility in which people are rendered speechless in public life, but exposed and unprotected in their homes ${ }^{23}$. Rather than taking for granted the Arendtian distinction between public and private, the point here is the interconnections between different scales created by the shifting borders: The forms of visibility and invisibility created at a societal, national scale, produces individual and community uncertainties and vulnerabilities in homeplaces and people's everyday lives.

Borderlands produce particular visions of and by the subjects inhabiting them ${ }^{24}$ : from the nation state scale, complex landscapes are reduced to homogenous spaces through a disembodied geopolitical reasoning 25 in which invisibility is produced at multiple scales $^{26}$. From the borderlands, the embodied and localised accounts of border shifts may effectively convey the production of visibility and invisibility. In formulating an epistemology of 'recognition', Honneth ${ }^{27}$ places the relationship between visibility and 
invisibility under scrutiny and points to two forms of in/visibility - a physical and a social form. Visibility in the physical form is understood as an individual identification, a situated and embodied subject, in contrast to a physical invisibility which represents a non-presence. In the second and more existential form, the relationship between visibility and invisibility is the contrast between existence and non-existence. It is when the two forms of in/visibility comes together that we can understand cognition and recognition in Honneth's proposition. The barbed wire, fences, military presence, checkpoints, flags and no-go zones in the borderlands dominate the landscape and create new mental maps that overpower the presence of the subjects. ${ }^{28}$ I show that the value of the presence of civilian subjects in the borderland is the continued claim by the nation state and groups aspiring to be the government of a particular territory. The territory is worthless without its citizens, but the citizens are only recognized as an abstract representation of the nation state: people in the Centre can only see projections of themselves in the borderlands; as a symbol of their own national identity and not the vulnerabilities that people experience. ${ }^{29}$ The power to imagine the borderlands is subject to those who can control the material practices of the border and, consequently, the representations of the border. In the spaces of the border, however, the people inhabiting the border continue to live everyday lives and negotiate the visibilities and invisibilities that are produced in the context of the very restriction that complex citizenship and the encounter with complex powers produce. 'Burdened agency' casts light on this constrained and structured context, where choices are often felt to be between bad and worse in a situation where people in the borderlands do not escape but have to confront the powers that threaten them ${ }^{30}$. 'Burdened agency', inspired by Meyer's work on victim paradigm and Cons and Dunn's work on camps and borderlands in Georgia, captures the particular types of force and coercion that come with a shifting border and that impact the agentive capacity people may generate. Through the lived reality of border-shifts, mundane types of social injustice that are of significance to the individual experience but often overlooked in more macro-political accounts of the border are highlighted. ${ }^{31}$ After a brief introduction of context and methodology, and in order to understand how tensions between visibility and invisibility are produced on the ground, I explore the material practices on the border, various forms of displacement and as a consequence, the public invisibility and private visibility that people experience with shifting borders.

\section{Shifting borders in Sri Lanka's and Georgia's border-areas}

Sri Lanka and Georgia have experienced shifting borders internally and geopolitically that have received varying degrees of international attention. Their histories and border-shifts differ, but some of the everyday experiences are similar. Both conflicts are about cessationist claims, where one group fights for independence from the state in which they are embedded. In Sri Lanka, the fight for a national homeland, Tamil Eelam, for the Tamil population in the north and the east of the country, came as a result of colonial and postcolonial experiences where the minority Tamil population felt increasingly marginalised by the Sinhalese dominated state. ${ }^{32}$ A number of militant 
groups emerged during the 1970s of which the LTTE later became the strongest. ${ }^{33}$ The war between LTTE and the Sri Lankan Armed Forces - fought between 1983 and 2009 created border areas with territories fluctuating between LTTE control and government control. In the territories under their control, the LTTE established government-like structures that would operate in parallel to the government offices that stayed in place in the war-zone throughout the conflict. LTTE's 'government structures' were developed further during a ceasefire agreement between 2002 and 2005 and they had their own court system, education ministry and development organisation. The LTTE controlled areas even operated in a different time zone from the Sri Lankan government controlled territories (with half an hour). In 2007, the Sri Lankan armed forces gained control over former LTTE-controlled areas in the east and in May 2009, the Sri Lankan armed forces, in a final battle in the north of the country had more or less eliminated the LTTE as a militant organisation on the island and reinstated a one-nation narrative.

South Ossetia was recognised as a separate ethnoterritorial region by the Soviet Georgian republic in April 1922.34 It got the status based on its distinctive ethnic composition and history as a region opposing the centralizing tendency of the Georgian state. With the dissolution of the Soviet Union and the establishment of the new nation states in 1991, Georgia abolished all autonomy of South Ossetia and prepared to seize its territory. ${ }^{35}$ There were several attempts by Georgian forces to take control of South Ossetia in 1991 and 1992, and the resulting violence left 20,000 people displaced. ${ }^{36} \mathrm{An}$ agreement between Georgia and Russia was signed in 1992 which saw the establishment of a joint control commission consisting of representatives from Georgia, Russia, North- and South Ossetia and the Organisation of Security and Co-operation in Europe (OSCE). The agreement established a security corridor that traversed the administrative border and was not divided into separate distinct spaces or areas of control $^{37}$. Since then, the Georgian-South Ossetian conflict has fluctuated between peaceful moments and high-intensity crises with thousands dead, maimed and displaced, together with a destroyed infrastructure, economy, trade, and social life in both Georgia and South Ossetia. ${ }^{38}$ Russia has played a complex role in the conflict, and is one of few countries who have accepted South Ossetia as a separate state. With the Rose Revolution in 2003 and a more Russian-hostile Georgian government, there was an intensification in tensions. In 2007, Putin offered all Ossetians Russian passports, which effectively made them Russian citizens. ${ }^{39}$ Increasingly sour relations between Georgia and Russia resulted in a war between Russia and Georgia that left 130,000 ethnic Georgians living in South Ossetia displaced without much prospect of returning. ${ }^{40}$ At the same time, the Georgians living on the Georgian side of the border were displaced during the conflict, but as I show later returned back to their homes after the war.

The Council of European Union brokered a ceasefire agreement in which both parties agreed to withdraw to their positions from before the hostilities. A Russian peacekeeping force was established which gave Russia access to a buffer zone with unclear boundaries ${ }^{41}$ and the first reports of barbed wire on the border between South 
Ossetia and Georgia followed in 2011. The main fencing activity by Russian forces administering the border started in 2013, splitting villages, cutting off access to agricultural land and markets. ${ }^{42}$ Then in August 2015, over night, the border moved - in places up to 300 metres - into Georgian territory, leaving a 1,6 km segment of the oil pipeline between Baku and Supsa outside Georgian territory. ${ }^{43}$ In some villages the border was moved during daytime, and in some places at night.

\section{Studying shifting borders}

The engagement with different geographical settings in which border-shifts take place, have enabled a richer understanding of what such geopolitical practices may mean in people's everyday lives. ${ }^{44}$ From both villages, I learnt the history of the place through people's narratives. Through the narratives I situated the bigger geopolitical events in the locations where they took place and enabled an understanding of the local context through which the borders travelled. In addition, and because I was keen to identify the chronological flow of events, I searched policy documents, various online news-outlets and, where available, academic literature in order to understand the wider context in which people created their narratives. In addition to working as a way of constructing a situated account of shifting borders, the narratives served as 'ontological narratives'45, through which I gained an understanding of how people made sense of and negotiated the border shifts.

There were many differences in how the narratives were collected in the two villages. In Sri Lanka, I conducted several periods of fieldwork on the east coast between 2008 and 2011 as part of a larger university collaboration on post-war recovery that I coordinated. ${ }^{46}$ Eastern Sri Lanka had not been the centre of attention of the conflict. I decided to focus my own research within the project (particularly focusing on displacement in conflict settings and the consequences post-conflict) in one village which I will term 'the Sri Lankan village' here. Through numerous qualitative interviews in the village, I realised that during the war, the villagers experienced that their homes fluctuated between LTTE- and government-control. In order to understand this process, I adopted a life history approach to understand how war-time experiences had shaped people's recovery after the war. In interviews, the shifting borders were used as a reference point to help date a particular experience: an event was described to have taken place when the checkpoint was in a particular location as a way of remembering when it had happened. After an initial life history interview with an individual or a household, I often came back to that same household several times over the next few years to chat, to catch up and to discuss further details of their daily life, their life histories and the shifting borders.

In Georgia, my research did not first and foremost concentrate on the border areas but on protracted internal displacement. I first started collecting data in Georgia in a larger evaluation on housing for the internally displaced in 2003, and later through two further research projects on long term displacement, I conducted fieldwork in the country in 
2010, 2012 and 2015. Again, life history interviews and follow up visits over the years from 2010 to 2015 were my main methods of data collection. I focused mainly on people displaced from Abkhazia, but I would also encounter and interview individuals and families from South Ossetia. Together with the IDP Women's Organisation "Consent" I had the opportunity to interview people in settlements that were built for those who could not return to South Ossetia. In December 2015, during two visits to two different border-villages on the Georgian side, I participated in meetings that "Consent" had with villagers to understand the conditions in which they were living. I was struck by the similarities in experiences and narratives that I had heard about border-shifts in the Sri Lankan village. In one of the villages, which from now on will be termed 'the Georgian village', I therefore conducted one focus group discussion and talked informally to people in the village during a one-day visit in 2015. It was during this visit that I was introduced to the experiences of the shifting border, the so-called 'creeping annexation' that people in the area had experienced a few months earlier.

The context of collecting data in both villages were one of militarization and securitization. I was unable to stay in any of the villages overnight - or any lengthy period at the time of fieldwork. For the Sri Lankan village, this resulted in many journeys up and down the coast between the main town and the village. While the data collected from the two villages differ and the two villages themselves are very different, the possibility of bringing in the material from the Georgian village helped to create what Cindi Katz ${ }^{47}$ terms a 'countertopography' of border-shifts. The experiences and narratives that were shared with me in both places helped to piece together an understanding of the experience and everyday-practices of geopolitical processes in which people become implicated. By following the same contour-line between the villages in Georgia and Sri Lanka, I was able to create a 'comparative imagination' 48 consisting of incomplete analytical insights from these two places.

\section{Lost access to context and power: the material impacts of the shifting border}

In both cases explored here, the emerging and shifting borders affected national identities as much as leaving marks on landscape and territory. In the case of Sri Lanka, the Sinhalese nationalist discourse represents Sri Lanka as a sacred island where Buddhists have a responsibility to preserve Buddhism and associated concepts of race, land and nation to be left untouched in its purity. ${ }^{49}$ For Georgia, Kabachnik ${ }^{50}$ has shown how the new borders and the breakaway regions create wounds and scars visually on the maps and in the national identity. However, the borders, marked by fences, checkpoints, military installations, landmines and flags, also constitute a materiality that restricts the actualisation of power and agency, preventing people's mobility, and taking away land and livelihoods from people. These are material changes that tie in with processes of making people invisible through a marginalization that effectively removes them from the gaze of the public. ${ }^{51}$ 
In the Georgian village, the impact of the shifting border was explained as a feeling of being stuck:

“The family's development stopped. We are frozen at one level. We are tied, don't know what to do. We are like in a prison. There is no place to run, I don't know what to do - we only exist here. If we just had a small room in Gori [the nearest city] we could live in, we would have left"52.

In the Sri Lankan village, an interviewee ${ }^{53}$ reflected on how her family had lived through the conflict between the LTTE and the Sri Lankan Armed Forces: "We were living like a drum, beaten from both sides". Their home was located right on one of the main locations of the recurring borders between the combating parties. The family lived at times in the area controlled by the Sri Lankan Government, and at other times in the area controlled by the LTTE, but most of the time they felt the presence of both militant actors. At night, LTTE would be more active among people, visiting their homes, asking them to contribute money, food and other assistance. During the day, the governmentforces controlled people's movements. Both the LTTE and the government had their own institutions and people thus had to relate to two state-like systems in their everyday lives. ${ }^{54}$

People and their homes become targets of regulation and surveillance in the name of ensuring 'security' (e.g. economic, physical, cultural) for particular populations, most often the economically and politically privileged. ${ }^{55}$ However, this securitization has different outcomes in the two villages. In the Sri Lankan village, power relations on either side of the line were not clearly defined. The migrating border separated Tamils from Tamils - not necessarily separating one group from the other. At the same time, however, the border in itself represented the Other - the Sinhalese state - and the line between the minority Tamils and the majoritarian Sinhalese state. Crossing the border was filled with anxiety, fear and the need to negotiate identities. ${ }^{56}$

In contrast, the shifting border in the Georgian village has meant the conflict has literally come closer to people's homes. People can hear gunshots when the soldiers on the other side practice their shooting skills: a constant reminder of the insecurity people live with. At the same time, the barbed wire, and later the fence, that was erected between Georgia and South Ossetia, cut people off from crossing the border and consequently, from mobility between the territories, from livelihoods and from seeing relatives on the other side. The moving border produces fear and people with land near the fence do not feel safe to cultivate the land as stories of kidnapping by border guards are common. Here, the 'Other' has to a larger extent than in the case of the Sri Lankan village, become a geopolitical concept that does not fully resonate with people's practices. The material practices of the border have curtailed contact and created hostility, separation and enemies. Symbolic practices and narratives - whether true or not - have helped villagers on the Georgian side to confirm their marginal position. One anecdote recounted how people on the other side of the border (South Ossetians) led their waste-water over to 
the Georgian side and into villagers' basements to destroy the year's harvest, animal fodder and other provisions and adding to the already precarious situation that people are experiencing.

In both villages, the material and symbolic impacts of the border-shifts created a context for what may be described as 'burdened agency'. In the following sections, I show how subjects in the borderlands struggle in a constrained context to recreate or maintain normal lives while negotiating conflicting powers. ${ }^{57}$

\section{Invisibility through Displacements 'in Place'}

People in the border areas in Sri Lanka and Georgia represent immobile groups. In the Sri Lankan village, the people who stayed during the war were those who often did not have the resources to move elsewhere in the country or abroad. During the war the LTTE would often tell all people in the village to go away for a couple of days during fighting. People would move to the jungle for a couple of days before returning to their homes, often to find that the checkpoints and border had shifted location, their houses damaged or looted, but with no place to go, no access to assistance, and with no other choice than to try to move on with life.

As I showed above, people in the Georgian village also feel stuck. When the border moved in 2015, people were taken by surprise. People whose land was now on the other side of the fence were given a few weeks after the border had moved to collect their harvest. In both cases, the shifting border created particular feelings of displacements: as a "simultaneously split and double existence - stretched across the multiple ruptures between 'here' and 'there'". ${ }^{8}$ With the shifting border, the definition of 'here' and 'there' changed. As Lubkeman ${ }^{59}$ has shown, those, who, during war are forced to remain in place, or just move away for shorter periods of time, tend to suffer more than those who move away to places where they may be closer to the centre and are given more attention as subjects of assistance. The suffering, also materialises in the various ways in which people in the borderland confronts and sustains the pressure that comes from shifting borders.

During the 2008 war, people in the Georgian village experienced kidnapping and physical violence, leading to a number of casualties. ${ }^{60}$ Displacement was frequent, and the sudden experience of not being protected by the state, not knowing who in the local community they could trust, and not feeling welcome elsewhere in the country created a sense of invisibility and of being forgotten by fellow citizens. Most people in the village moved away for a short time during the conflict. They stayed in temporary collective centres in kindergartens and other institutions while they were waiting to return: 
"We were assisted by the government [during displacement]. But not from the beginning. The capital didn't believe in our need to get out of our areas, but when the war came close to Tbilisi, then people realised the danger and more assistance was directed towards us at the time. But in the beginning they told us: "Why didn't you stay back and protect your communities?" But then when the bomb fell in Tbilisi, then they understood. People were mobilised. The 1990s IDPs also helped ${ }^{61}$. They opened the bathrooms for us. They knew our situation."62

When the war was over, people whose properties were in villages on the Georgian side of the border had to go back to their places. Ethnic Georgians displaced from South Ossetia could not return and were provided with housing in new settlements along the main road between Tbilisi and Gori and close to the border. ${ }^{63}$ Upon return to the Georgian village, some people found their houses destroyed, while most had been damaged in some way. During the first two years they received some humanitarian aid such as food and firewood. People in the Georgian village, however, felt that they were not treated as real displaced people as they had not moved for long and could return.

\section{Outside the gaze: speechless}

"Its all psychological at the moment. Every night we can hear the shooting in the night, we feel that we are constantly in a war situation." 64

Some borderlands are located outside the grip of institutions that govern from the centre. In such spaces, there may be a state of opportunity or lawlessness. ${ }^{65}$ These interstitial zones may represent freedom and opportunity, sites where there is a possibility for change and that are "lively but not entirely safe" 66 , but at the same time they are highly constrained spaces. In the Sri Lankan village, when people came back from their days of displacement during the war, the government forces questioned them: "Where did you go, who asked you to go?" Survival was linked to learning how to speak, how to answer the questions by the government forces, and how to deal with the multiple requests from the LTTE. "What was your strategy to survive?" I asked. "Not to be seen" an interviewee responded. The less seen and the more invisible, the less trouble one would experience. Invisibility becomes the last resort when other forms of protection are not available, a strategy adopted when the border shifts are unpredictable and the powers inhabiting the borderlands volatile ${ }^{67}$. Making oneself invisible takes place through ways of speaking, dressing and presenting oneself to ensure self-protection. ${ }^{68}$ On the contrary, the people in the Georgian village felt that they were made invisible. I asked people if they had protested when the border moved. The interviewees said that they had not protested directly to the soldiers when it happened, but they had protested with official letters and a list had been made of those people who lost their lands. 
Invisibility, as a strategy in the case of Sri Lanka and as enforced invisibility imposed by the state in Georgia, was coupled with what Arendt understands as a natural visibility. This created exposure in their homes - a sense of not being safe in their dwellings. Fear - and these specific relations of subordination - structured people's view of the options available to them. ${ }^{69}$ In the Sri Lankan village, invisibility was not only a strategy people took on themselves, it was also imposed on them. War and the shifting borders deprived people of the Sri Lankan village of a voice, their strategy to survive was to be silent and invisible. They could not pursue their citizenship and concomitant rights ${ }^{70}$. In the Georgian village, the fear that accompanied the shifting border was a predominant emotion that governed daily life and contributed to render people speechless, passive and with few possibilities to invest in a future in the borderland where they feel stuck.

\section{Conclusions: public invisibility, natural visibility}

Theorising borders becomes a way of analysing the social. In the context of bordershifts, I have shown that despite the continuous feeling of being stuck, people in the borderlands develop capacities to act within the particular set of restrictions that the changing borders create. By living and surviving in the borderlands, people become the crossroads as Anzaldúa's poem shows. People inhabiting the borderland represent the 'intersection of two or more roads'71: the central node at which geopolitical powers fight for sovereignty and dominance. These borderland-subjects relate to, negotiate with and mediate between different powers at the same time, they represent the points at which different scales come together. Crossroads, however, may also refer to the crucial point where 'decisions are being made with far-reaching consequences' ${ }^{72}$. By living in the borderlands and experiencing the split existence between here and there as the borders shift, people contribute to constitute the border by the day-to-day decisions they are forced to make to sustain their lives. Decisions to avoid or confront border-practices, making themselves (in)visible, come into interaction with the geopolitical actors dependent on the border-subjects to maintain their power and create particular processes of peripheralisation.

In the Sri Lankan village on the east coast, the war ended in 2007, people moved back home to a one nation narrative, determined to rebuild their lives. After years of militarisation, shifting borders and checkpoints, people could gradually live with less fear. Life had become easier, they said, because of the presence of only one master. However, the invisibility continued in multiple ways and the area is still one of the most marginal and poorest of the country. In January 2017, when I revisited the village, I learnt that language is a most significant symbolic marker of the afterlife of the material and shifting borders during the war. People in the Sri Lankan village speak Tamil and most people cannot read or speak Sinhala. However, most officials in police and local government officers will only speak and write letters in Sinhala. People continue to be rendered peripheral and invisible. The border areas continue to be spaces of existential, 
social, political and legal limbo where disturbing memories of past conflict and violence are mapped onto present-day socio-economic asymmetries and inequalities. ${ }^{73}$

Similarly in Georgia, the significance of people's physical presence in the borderland for Georgia's geopolitical and national narrative shapes the nature of their invisibility. As this paper has shown, the border is far from just a line through a territory. 'Borderization' is as much about information and image as about military capacity. ${ }^{74}$ Control over territories takes place through intimidation and threats. It is not a military invasion but a "creeping occupation" and subsequent take-over of strategic positions in breakaway regions. Reality and representation are specially and intimately linked. ${ }^{75}$ Border-practices continue to produce people in the borderlands as the Other and the borderlands are marginal spaces, where people negotiate their everyday spaces through burdened agency. There is a constant feeling of uncertainty, low trust and being exposed to conflict and different forms of violence.

The particular production of invisibility is noticeable in both cases, but may not be the same in other cases of shifting border. In the two cases presented here, the role of invisibility also differs. Unpacking the tensions between visibility and invisibility helps to understand the processes through which the borderlands and the subjects who inhabit them are rendered peripheral. I have shown how these contingent processes take place through material impacts of border shifts, the experience of 'displacement in place' and the invisibilities produced in the border areas in the context of the fear for the multiple, contradicting and intersecting power relations that people have to relate to. ${ }^{76}$ The public recognition - and visibility that would, in Hannah Arendt's understanding, earn people individual rights and protection is currently out of reach for people in the borderlands who are publicly invisible. ${ }^{77}$ An engagement with feminist geopolitics enables a mode of interrogating and exposing the grounds for knowledge production ${ }^{78}$ that takes place in the periphery. With the comparative imagination across the two villages, I have produced a countertopography of border shifts. The unpacking and exposure of violence and the production of suffering that the shifting borders produce could be used to re-claim some the accompanying rights that come with public visibility and recognition. The public recognition - and visibility that would, in Hannah Arendt's understanding, earn people individual rights and protection is, however, currently out of reach for people in the borderlands. ${ }^{79}$

\footnotetext{
1 Without borders
} 
2 G. Anzaldua, Borderlands. La Frontera. The New Mestiza. (San Francisco: Aunt Lute Books 1987) pp. $216-217$.

3 Ibid

4 J. Goodhand, 'Epilogue. The view from the border', in B. Korf and T. Raemaekers (eds.), Violence on the Margins. States, Conflicts and Borderlands. (New York: Palgrave 2015) pp 247-264.

5 G. Agamben, 2005. States of Exception. Translated by Kevin Attell. (Chicago: The University of Chicago Press).; E.F. Isin and K. Rygiel. 'Abject Spaces: frontiers, zones, camps', in E. Dauphinee and C. Masters (eds.), Logics of Biopower and the War on Terror (Houndmills: Palgrave 2007) pp. 181-203.

${ }^{6}$ L. Dowler and J. Sharp, 'A feminist geopolitics?', Space and Polity 5/3 (2001) pp. 165-176; J. Hyndmand, 'Mind the gap: bridging feminist and political geography through geopolitics', Political Geography 23 (2004) pp. 307 322; S. Koopman, 'Alter-geopolitics. Other securities are happening', Geoforum 42/3 (2011) pp.274-284.

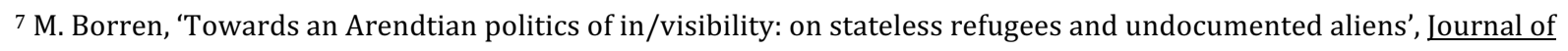
European Ethics Network 15/2 (2008) pp. 213-237.

8 H. Arendt, The Human Condition (Chicago and London: The University of Chicago Press 1958)

${ }^{9}$ R. Brubaker, 'Aftermaths of empire and the unmixing of peoples: historical and comparative perspectives' Ethnic and

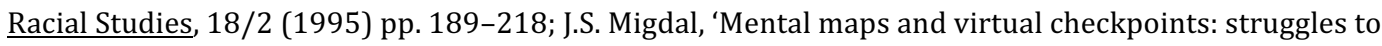
construct and maintain state boundaries', in J.S. Migdal (ed.), Boundaries and Belonging: states and societies in the struggle to shape identities and local practices (Cambridge: Cambridge University Press 2004) pp.3-23.

10 C, Dahlman and G.O. Tuathail, 'Broken Bosnia: The localized Geopolitics of Displacement and Return in Two Bosnian Places', Annals of the Association of American Geographers 95 (2005) pp. 644-662.; N. Megoran, 'For ethnography in political geography: experiencing and re-imagining Ferghana Valley boundary closures', Political Geography 26 (2006) pp. 622-640.

11 J. Goodhand, 'Stabilising a victor's peace? Humanitarian action and reconstruction in eastern Sri Lanka', Disasters 34 (2011) pp. 342-367.; K. Höglund and C. Orjuela, 'Winning the peace: conflict prevention after a victor's peace in Sri Lanka', Contemporary Social Science 6/1 (2011) pp. 19-37.

12 P. Novak, 'The Flexible Territoriality of Borders', Geopolitics 16/(2011) pp. 741-767.; C. Rumford, 'Introduction. Theorizing borders', European Journal of Social Theory 9 (2006) 155-169.

13 J. Williams and V. Massaro, 'Feminist Geopolitics: Unpacking (In)Security, Animating Social Change', Geopolitics 18/4 (2013) pp.751-758.; Dowler and Sharp note 7.

14 J. Casolo and S. Doshi, 'Domesticated Dispossessions? Towards a Transnational Feminist Geopolitics of Development', Geopolitics 18/4 (2013) pp. 800-834.

15 C. Brambilla, 'Exploring the critical potential of the borderscapes concept', Geopolitics 20 (2015) pp.14-34.

16 Casolo and Doshi note 15; J. Hyndman, 'Towards a Feminist Geopolitics', Canadian Geographer - Geographie Canadien 45 (2001) pp. 210-222; S.H. Smith, 'The Domestication of Geopolitics: Buddhist-Muslim Conflict and the Policing of Marriage and the Body in Ladakh, India', Geopolitics 14(2009) pp. 197-218.

17 J. Hyndman, 'Feminist Geopolitics Revisited: body counts in Iraq', The Professional Geographer 59/1/ (2007) pp. 35-46; R. Pain and L. Staeheli, 'Introduction: intimacy-geopolitics and violence', Area 46/4/ (. 2014.) pp. 344360.

18 E. Balibar, We, the people of Europe? Reflections on transnational citizenship. Translated by James Swenson. (Princeton: Princeton University Press 2009); E. Brunet-Jailly, 'Special Section: Borders, borderlands and theory: an introduction', Geopolitics 16 (2011) pp. 1-6; A. Mountz, 'Border politics: spatial provision and geographical precision', in Interventions on rethinking 'the border' in border studies, Political Geography 30 (2011) pp. 61-69.

${ }^{19}$ D. Newman and A. Paasi, 'Fences and neighbours in the postmodern world: boundary narratives in political geography', Progress in Human Geography 22/2 (1998) pp. 186-207.

20 J. Hyndman and M. de Alwis, 'Bodies, Shrines, and Roads: violence (im)mobility and displacement in Sri Lanka', Gender, Place and Culture 11/4 (2004) pp. 535-557.; P. Jeganathan, 'Checkpoint: Anthropology, identity and the state', in V. Das and D. Poole (eds.), Anthropology in the Margins of the State (Oxford: James Curry 2004) pp. $67-80$. 
21 V. Das, Life and words: violence and descent into the ordinary. (Berkeley: University of California Press 2007) pp. 9: "It is not only violence experienced on one's body in these cases, but also the sense that one's access to context is lost that constitutes a sense of being violated. The fragility of the social becomes embedded in a temporality of anticipation since one ceases to trust that context is in place".

22 Ibid.

${ }^{23}$ Borren (note 8): I am not referring to a distinction between public and private worlds here, but rather the understanding of people's social status and the feeling of security and insecurity in people's homes. The distinction between public and private in Arendt's work by having a public status, being recognised publicly, you also have private and individual rights of protection. See also P. Owens, 'Distinctions, distinctions: 'public' and 'private' force?', International Affairs 84/5 (2008) pp. 977-990.

24 G. Ò Tuathail, 'Dis/placing the geo-politics which one cannot want', Political Geography 19 (2000) pp. 385-396.

25 A. Ingram, 'Alexander Dugin: geopolitics and neo-fascism in post-Soviet Russia', Political Geography 20 (2001) pp. 1029-1051.; Hyndman note 7.

${ }^{26} \mathrm{C}$. Nordstrom, Shadows of war: violence, power, and international profiteering in the twenty-first century. (Berkeley, California: University of California Press 2004).

27 A. Honneth, 'Invisibility: on the epistemology of 'recognition", Proceedings of the Aristotelian Society. Supplementary Volumes 75 (2001) pp. 111-139.

28 J. Migdal (ed.), Boundaries and Belonging. States and Societies in the Struggle to Shape Identities and Local Practices. (Cambridge: Cambridge University Press 2004)

${ }^{29}$ M.C. Nussbaum, 'Invisibility and Recognition: Sophocles' Philocetes and Ellison's Invisible Man', Philosophy and Literature 23/2 (1999) pp. 257-283.

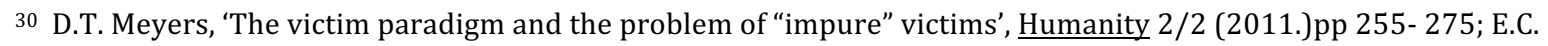
Dunn and J. Cons, 'Aleatory Sovereignty and the Rule of Sensitive Spaces', Antipode 46/1 (2014) pp. 92-109.

31 L. McNay. 'The Misguided Search for the Political' (Cambridge: Polity Press, 2015), Hyndman note 17.

32 F. Azmi, 'To go or not to go: struggle for belonging among second generation Muslim IDPs in Kalpitiya in Puttalam district in the context of post war resettlement', in D. Herath and K.T. Silva (eds.) Healing the wounds of war (Sri Lanka: ICES 2012) pp.167-192.; F. Azmi, 'Impacts of internal displacement on Women's agency in two Displacement contexts in Sri Lanka', in C. Brun, P. Blaikie and M. Jones (eds.) Unravelling marginalization, Voicing change. Alternative visions and path of development (Farnham: Ashgate Publishing 2014) pp. 243257.; R. Rotberg, (ed.) Creating Peace in Sri Lanka. Civil War and Reconciliation (Washington D.C.: Brookings Institution Press 1999).

${ }^{33}$ C. Brun,' Women in the local/global fields of war and displacement', Gender, Development and Technology 9/1

(2005) pp. 57-80.

34 G. Ò Tuathail, 'Russia's Kosovo: A Critical Geopolitics of the August 2008 war over South Ossetia', Eurasian Geography and Economics 49/6 (2008) pp. 670-705.

35 Ò Tuathail note 34 .

36 IDMC, Georgia: New IDP Strategy awaits implementation (Geneva: IDMC 2007) http://www.internaldisplacement.org/assets/library/Europe/Georgia/pdf/Georgia-October-2007.pdf, accessed 10.12.16.

37 Ó Tuathail note 34.

38 G. Jasutis, 'Forward-looking solutions for the Georgian and South Ossetian Conflict towards reconciliation', Baltic Journal of Law \& Politics 6/2 (2013) pp. 24-49.

${ }^{39}$ E.C. Dunn and M. Bobick, 'The Empire Strikes Back: War Without War and Occupation Without Occupation in the Russian Sphere of Influence', American Ethnologist 41/3 (2014) pp. 405-413.

40 IDMC, Georgia: at least 128,000 people internally displaced by renewed conflict (Geneva: IDMC 2008) http://www.internal-displacement.org/assets/library/Europe/Georgia/pdf/Georgia-Overview-21Aug08.pdf, $\underline{10.12 .16}$

41 Ó Tuathail note 34.

42 G. Tavadze, 'New Russian imperialism and Georgia: violent spatial practices, disrupted places, and destabilised spaces', European Scientific Journal 2 (2014), pp. 127-136. 
43 BBC, 'EU warning over Russia 'land grab' in South Ossetia border row', (2015) http://www.bbc.com/news/worldeurope-33549462, accessed 10.12 .16

44 Ibid.

45 M. Somers, 'The narrative constitution of identity: a relational and network approach', Theory and Society 23 (1994), pp. 605-649.

46 F. Azmi, C. Brun and R. Lund, 'Young people's everyday politics in post-conflict Sri Lanka', Space and Polity 17/1 (2013) pp. 106-122.

${ }^{47}$ C. Katz, 'On the grounds of globalization: a topography for feminist political engagement', Signs 26 (2001), pp. 1213 $-1234$.

48 P. 5 in J. Robinson, 'Thinking cities through elsewhere: comparative tactics for a more global urban studies', Progress in Human Geography 40 (2016), pp. 3-29.

${ }^{49}$ N. Tiruchelvam, 'The politics of federalism and diversity in Sri Lanka' in Y. Ghai (ed.) Autonomy and Ethnicity. Negotiation Competing Claims in Multi-Ethnic States (Cambridge : Cambridge University Press 2000) pp. 197218.

50 P. Kabachnik, 'Wounds that Won't Heal: Cartographic Anxieties and the Quest for Territorial Integrity in Georgia', Central Asian Survey 31/1 (2012) pp. 45-60.

${ }^{51}$ L. Hammond, 'Strategies of invisibilization. How Ethiopia's resettlement programme hides the poorest of the poor', Journal of Refugee Studies 21/4 (2008) pp. 517-536.; Ingram note 26.

52 Group interview December 2015, Georgian village

53 Interview March 2009, Sri Lankan village.

54 C. Brun, 'Birds of Freedom. Young people, LTTE and representations of gender, nationalism and governance in northern Sri Lanka', Critical Asian Studies 40/3 (2008) pp. 399-422.; N.Van Hear and C. Brun, 'Between the local and the diasporic: the shifting centre of gravity in war-torn Sri Lanka's transnational politics', Contemporary South Asia 20/1 (2012) pp. 61-75.

55 Williams and Massaro note 14.

56 Hyndman and de Alwis note 21.

57 Dunn and Cons note 32.

${ }^{58}$ A. Bammer, 'Introduction', in A. Bammer (ed.) Displacements. Cultural Identities in Question, (Bloomington : Indiana University Press 1994) p. xii.

59 S.C. Lubkeman, 'Involuntary immobility: On a theoretical invisibility of forced migration studies', Lournal of Refugee Studies 21/4 (2008) pp. 454-475.

60 ÒToathail note 35.

61 The people who were displaced in the 1990s from South Ossetia and Abkhazia and still live with the status as Internally Displaced Persons (IDPs).

62 Group interview Georgian Village December 2015.

63 E.C. Dunn, 'Notes Towards an Anthropology of Nothing: Humanitarianism and the Void in the Republic of Georgia', Slavic Review 73/2 (2014) pp. 287-306.

64 Interview December 2015, Georgian village.

65 J. Goodhand, 'Frontiers and Wars: the opium economy of Afghanistan', Journal of Agrarian Change 5 (2005) pp. 191-216.; U. Hannerz, Flows, Boundaries and Hybrids: Keywords in Transnational Anthropology. WPTC-2K-02 Department of Anthropology (Stockholm: Stockholm University 2002).

${ }^{66}$ Hannerz ibid pp. 12.

67 T. Polzer and L. Hammond, 'Invisible Displacement', Journal of Refugee Studies, 21 (2008) pp. 417-431.

68 Hyndman and de Alwis note 21.

${ }^{69}$ S. Mahmood, 'Feminist theory, embodiment and the docile agent: some reflections on the Egyptian Islamic Revival', Cultural Anthropology, 16 (2001) pp. 202-236.; J. Scott, Weapons of the weak. (New Haven: Yale University Press 1985).

${ }^{70}$ An example of this deprivation of voice was the LTTE's prevention of people to vote in general elections, such as the presidential elections of 2005. 
71 Merriam-Webster Dictionary, 'crossroad', https://www.merriam-webster.com/dictionary/crossroad, accessed 02.07, 17

72 Oxford Dictionary, 'crossroads', https://en.oxforddictionaries.com/definition/crossroads, accessed 02.07.17

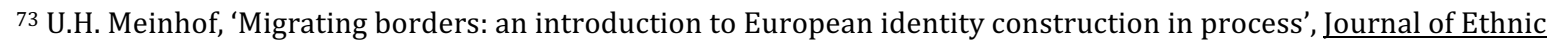
and Migration Studies 29 (2003) pp. 781-796.

74 Dunn and Bobick note 40 p.204.

75 Dunn and Cons note 32.

76 Anzaldua note 2.

77 Arendt note 9, Owens note 24.

78 Hyndman note 17

${ }^{79}$ Arendt note 9, Owens note 24. 